\title{
Construction of New and Old Kinetic Energy Conversion Monitoring Index Based on Electricity Demand Data
}

\author{
Lili Zhang ${ }^{1, a^{*}}$, Chenrui $\mathrm{Wu}^{1, \mathrm{~b}}$ and Xiandong Tan ${ }^{1, \mathrm{c}}$ \\ ${ }^{1}$ State Grid Energy Research Institute Co., Ltd., Beijing, 102209, China \\ azhanglili@amss.ac.cn, ${ }^{\mathrm{b}}$ wuchenrui@sgeri.sgcc.com.cn, ${ }^{\mathrm{c}}$ tanxiandong@sgeri.sgcc.com.cn \\ "Corresponding author
}

Keywords: New and Old Kinetic Energy Conversion, Monitoring Index, Power Demand.

\begin{abstract}
This paper builds a new and old kinetic energy conversion monthly monitoring index system based on power demand data, and measures the new and old kinetic energy conversion monthly index of Shandong. Since 2014, the old and new kinetic energy conversion index maintained a low level of fluctuation, indicating that the effect of the conversion of old and new kinetic energy in Shandong is still insufficient, and the succession is weak. The old kinetic energy has achieved remarkable results in eliminating backward production capacity, but the new kinetic energy failed to achieve effective connection conversion. Specifically, before 2013, the new kinetic energy monthly index was mostly higher than the old kinetic energy monthly index. The rapid development of the new kinetic energy industry is the leading force to promote the conversion of new and old kinetic energy in Shandong, while the old kinetic energy industry has hindered the conversion process of new and old kinetic energy in Shandong. Since 2013, the old kinetic energy index is mostly higher than the new kinetic energy index, indicating that the old kinetic energy has achieved remarkable results in eliminating backward production capacity, but the lack of development of the new kinetic energy industry has made the conversion of new and old kinetic energy slower.
\end{abstract}

\section{Introduction}

Since the introduction of the "new and old kinetic energy conversion", it has played an effective role in guiding and promoting the economic transformation and development. However, the current "new and old kinetic energy conversion" results are mainly evaluated by indicators such as the proportion of new economy and the development of high-tech industries. Sun Xiumei used the analytic hierarchy process and fuzzy comprehensive evaluation method to select 19 factors from the aspects of quality and efficiency, innovation and development, opening up and environmental protection and people's livelihood, and constructed a new and old kinetic energy conversion performance evaluation index system. Compare and analyze the performance evaluation of new and old kinetic energy conversion between Shandong Province and Hebei, Zhejiang, Jiangsu and other three eastern coastal provinces [1]. Zhang Lingling constructed an index system for the transformation of the old and new kinetic energy of the economy, and used the regular method to measure the economic benefits, innovation development, opening up, green development, and public service indices of Wuhan and 14 sub-provincial and above cities in 2017. On this basis, the degree of new and old kinetic energy conversion is measured [2]. Li Mengxin measured and evaluated the development status of new kinetic energy cultivation in western China at the present stage by constructing a theoretical framework and indicator system for nurturing new kinetic energy, in order to put forward the policy recommendations and the appropriate path for the development of new kinetic energy in the western region of China [3]. From the statistical perspective, Liu Qitao used the relevant data of Qingdao City in Shandong Province as an example to make a basic analysis measure. Through the construction of the index system and the quantitative measurement method of the index, the new and old kinetic energy conversions in Qingdao were analyzed [4]. Xu Pengjie defines the economic balance development with the convergence of regional and urban and rural residents' income, and builds a comprehensive indicator system to measure the province's kinetic energy conversion and basic public service level [5]. 
Due to the limitations of the selection of evaluation indicators, the commonly used evaluation indicators have the problems of low acquisition frequency and long lag period. The conversion of old and new kinetic energy is a structural transformation process of continuous change, and timely monitoring is an important task. The existing evaluation index system for the performance of new and old kinetic energy conversion is mainly based on annual data. Although the comprehensive evaluation of the new and old kinetic energy conversion results is carried out from multiple dimensions, the data acquisition of the indicator system is relatively lagging. The main indicators come from the statistical yearbooks, which have a lag period of one year. In order to monitor the new and old kinetic energy conversion status in a timely and effective manner, this paper will construct a new and old kinetic energy conversion monthly monitoring index system and measure the new and old kinetic energy conversion monthly index. Electricity is an important energy source. Power demand data can feedback economic operation status in a timely and effective manner. This paper builds a new and old kinetic energy conversion monthly monitoring index system based on power demand data, and takes Shandong as an example to measure its new and old kinetic energy conversion monthly index.

\section{New and old kinetic energy conversion monthly monitoring index}

\subsection{Indicator selection principle}

The construction of the new and old kinetic energy conversion monthly monitoring index system mainly follows the following principles: 1 . Systematic principle: based on the old and new kinetic energy conversion theory, the selected indicators must be relevant, and constitute a certain hierarchical function reflecting the conversion of new and old kinetic energy, combining new kinetic energy and old kinetic energy to reflect the evolution of new and old kinetic energy; 2 . Operational principle: the selected indicators must be quantifiable, individual indicators should be identifiable, and indicators should have obvious boundaries. The caliber must be consistent and comparable; 3 . The principle of suitability: combined with the characteristics and needs of Shandong's economic development, the selected indicators should fully reflect the indicators of the old and new kinetic energy industries in Shandong's industrial structure and development planning.

\subsection{Index construction method}

The construction of the indicator system includes four steps: index selection, index processing, weight calculation and index synthesis.

\subsubsection{Indicator selection}

1. In order to comprehensively monitor the new and old kinetic energy conversions monthly, the index system is constructed based on the electricity demand data of different industries. See Table 1 for details. The indicator system is calculated using data from February 2008 to June 2019.

Table 1 New and old kinetic energy conversion monthly monitoring index system

\begin{tabular}{|c|c|c|c|c|c|}
\hline $\begin{array}{l}\text { Primary } \\
\text { indicator }\end{array}$ & $\begin{array}{l}\text { Secondary } \\
\text { indicator }\end{array}$ & $\begin{array}{c}\text { Third level } \\
\text { indicator }\end{array}$ & Fourth level indicator & $\begin{array}{l}\text { Symbol } \\
\text { code }\end{array}$ & $\begin{array}{l}\text { Indicator } \\
\text { attribute }\end{array}$ \\
\hline \multirow{7}{*}{$\begin{array}{l}\text { New and } \\
\text { old kinetic } \\
\text { energy } \\
\text { conversion } \\
\text { evaluation }\end{array}$} & \multirow{4}{*}{$\begin{array}{l}\text { Old kinetic } \\
\text { energy } \\
\text { industry }\end{array}$} & \multirow{4}{*}{$\begin{array}{l}\text { High energy } \\
\text { consumption } \\
\text { industry }\end{array}$} & $\begin{array}{l}\text { Chemical raw materials and } \\
\text { chemical manufacturing }\end{array}$ & $\mathrm{X} 1$ & Negative \\
\hline & & & $\begin{array}{l}\text { Non-metallic mineral products } \\
\text { industry }\end{array}$ & $\mathrm{X} 2$ & Negative \\
\hline & & & $\begin{array}{l}\text { Ferrous metal smelting and rolling } \\
\text { processing industry }\end{array}$ & $\mathrm{X} 3$ & Negative \\
\hline & & & $\begin{array}{l}\text { Non-ferrous metal smelting and } \\
\text { rolling processing industry }\end{array}$ & $\mathrm{X} 4$ & Negative \\
\hline & \multirow{3}{*}{$\begin{array}{l}\text { New } \\
\text { kinetic } \\
\text { energy } \\
\text { industry }\end{array}$} & $\begin{array}{l}\text { Pharmaceutical } \\
\text { manufacturing }\end{array}$ & Pharmaceutical manufacturing & $\mathrm{X} 5$ & Positive \\
\hline & & \multirow{2}{*}{$\begin{array}{l}\text { Equipment } \\
\text { manufacturing }\end{array}$} & Metal products industry & X6 & Positive \\
\hline & & & $\begin{array}{l}\text { General and special equipment } \\
\text { manufacturing }\end{array}$ & $\mathrm{X} 7$ & Positive \\
\hline
\end{tabular}




\begin{tabular}{|c|c|c|c|c|c|}
\hline $\begin{array}{l}\text { Primary } \\
\text { indicator }\end{array}$ & $\begin{array}{l}\text { Secondary } \\
\text { indicator }\end{array}$ & $\begin{array}{l}\text { Third level } \\
\text { indicator }\end{array}$ & Fourth level indicator & $\begin{array}{l}\text { Symbol } \\
\text { code }\end{array}$ & $\begin{array}{l}\text { Indicator } \\
\text { attribute }\end{array}$ \\
\hline & & & $\begin{array}{l}\text { Transportation, electrical and } \\
\text { electronic equipment manufacturing }\end{array}$ & $\mathrm{X} 8$ & Positive \\
\hline & & \multirow[t]{6}{*}{$\begin{array}{l}\text { Modern service } \\
\text { industry }\end{array}$} & $\begin{array}{l}\text { Transportation, warehousing and } \\
\text { postal services }\end{array}$ & X9 & Positive \\
\hline & & & $\begin{array}{l}\text { Information transmission, software } \\
\text { and information technology services }\end{array}$ & $\mathrm{X} 10$ & Positive \\
\hline & & & Financial industry & $\mathrm{X} 11$ & Positive \\
\hline & & & Leasing and business services & $\mathrm{X} 12$ & Positive \\
\hline & & & $\begin{array}{l}\text { Education, culture, sports and } \\
\text { entertainment }\end{array}$ & $\mathrm{X} 13$ & Positive \\
\hline & & & Health and social work & $\mathrm{X} 14$ & Positive \\
\hline
\end{tabular}

\subsubsection{Data processing}

The first step is standardization. Standardization using extreme value normalization. For the negative indicator, it is standardized by the following formula:

$$
x_{i j}^{\prime}=\left(\max _{j}\left(x_{i j}\right)-x_{i j}\right) /\left(\max _{j}\left(x_{i j}\right)-\min _{j}\left(x_{i j}\right)\right)
$$

For the forward indicator, it is standardized using the following formula:

$$
x_{i j}^{\prime}=\left(x_{i j}-\min _{j}\left(x_{i j}\right)\right) /\left(\max _{j}\left(x_{i j}\right)-\min _{j}\left(x_{i j}\right)\right)
$$

Seasonal adjustments are made to monthly data after standardization of indicators. Analysis was performed using data that eliminated seasonal factors.

\subsubsection{Index weight calculation}

The information entropy is used to calculate the hierarchical weight. First, the entropy value $\mathrm{H}$ of each index is calculated by using the standardized data $\mathrm{x}$. it is calculated by the following formula:

$$
H_{j}=-\frac{1}{\ln (n)} \sum_{i=1}^{n} x_{i j} \ln \left(x_{i j}\right)
$$

Then, using the result of equation (3), the degree of discrimination $\mathrm{F}$ is calculated, it is calculated by the following formula:

$$
F_{j}=1-F_{j}
$$

Finally, the weight $w$ of each evaluation index is calculated, and the calculation formula is:

$$
W_{j}=\frac{F_{j}}{\sum_{k=1}^{n} F_{k}}
$$

\subsubsection{Composite index calculation}

The composite index method is used to calculate the new and old kinetic energy monthly index, the old kinetic energy monthly index and the new kinetic energy monthly index. First, calculate the symmetrical rate of change for a single indicator, as follows:

$$
C_{i}^{t}=200\left(x_{i}^{t}-x_{i}^{t-1}\right) /\left(x_{i}^{t}+x_{i}^{t-1}\right)
$$

Where $C_{i}^{t}$ is the symmetrical rate of change of indicator $\mathrm{i}$ in year $\mathrm{t}$, and $x_{i}^{t}$ and $x_{i}^{t-1}$ are the normalized data of indicator $\mathrm{i}$ in $\mathrm{t}$ and $\mathrm{t}-1$ years, respectively. Then, the order mean averaging $A_{i}, \mathrm{~N}$ is the normalized period.the formula is as follows:

$$
A_{i}=\sum_{t=2}^{N}\left|C_{i}^{t}\right| /(N-1)
$$

Then the standard symmetrical rate of change is standardized, and the multi-index weighted average is calculated. The calculation formula is as follows:

$$
\begin{gathered}
S_{i}^{t}=C_{i}^{t} / A_{i} \\
R^{t}=\sum_{i=1}^{k} S_{i}^{t} W_{i} / \sum_{i=1}^{k} W_{i}
\end{gathered}
$$


$S_{i}^{t}$ is the standardized symmetric rate of change, $R^{t}$ is the weighted average of the multiple indicators symmetric rate of change, and $W_{i}$ is the index weight calculated by the information entropy method. Next, calculate the composite index of the old and new kinetic energy conversion monthly index, the old kinetic energy index and the new kinetic energy index. Let $I^{1}=100$, determine the base year average $\bar{I}^{0}$, and then press the two formulas to calculate the composite index $C I^{t}$ :

$$
\begin{gathered}
I^{t}=I^{t-1} \frac{200+R^{t}}{200-R^{t}} \\
C I^{t}=\frac{I^{t}}{\bar{I}^{0}} \times 100 \%
\end{gathered}
$$

\section{Index application}

According to the above steps, the monthly monitoring index of Shandong new and old kinetic energy is measured. First, after processing the data, the index weight is measured by applying the information entropy method, as shown in Table 2:

\begin{tabular}{|c|c|c|c|c|c|c|}
\hline $\begin{array}{l}\text { Primary } \\
\text { indicator }\end{array}$ & $\begin{array}{l}\text { Secondary } \\
\text { indicator }\end{array}$ & $\begin{array}{l}\text { Weight of } \\
\text { secondary } \\
\text { indicator }\end{array}$ & $\begin{array}{l}\text { Third level } \\
\text { indicator }\end{array}$ & Fourth level indicator & $\begin{array}{l}\text { Weight of } \\
\text { fourth } \\
\text { level } \\
\text { indicator }\end{array}$ & $\begin{array}{c}\text { Final } \\
\text { weight }\end{array}$ \\
\hline \multirow{14}{*}{$\begin{array}{l}\text { New and old } \\
\text { kinetic } \\
\text { energy } \\
\text { conversion } \\
\text { evaluation }\end{array}$} & \multirow[t]{4}{*}{$\begin{array}{l}\text { Old kinetic } \\
\text { energy industry }\end{array}$} & \multirow[t]{4}{*}{0.288} & \multirow[t]{4}{*}{$\begin{array}{l}\text { High energy } \\
\text { consumptio } \\
n \text { industry }\end{array}$} & $\begin{array}{l}\text { Chemical raw materials and } \\
\text { chemical manufacturing }\end{array}$ & 0.252 & 0.072 \\
\hline & & & & $\begin{array}{l}\text { Non-metallic mineral } \\
\text { products industry }\end{array}$ & 0.247 & 0.071 \\
\hline & & & & $\begin{array}{l}\text { Ferrous metal smelting and } \\
\text { rolling processing industry }\end{array}$ & 0.251 & 0.072 \\
\hline & & & & $\begin{array}{l}\text { Non-ferrous metal smelting } \\
\text { and rolling processing } \\
\text { industry }\end{array}$ & 0.251 & 0.072 \\
\hline & \multirow[t]{10}{*}{$\begin{array}{l}\text { New kinetic } \\
\text { energy industry }\end{array}$} & \multirow[t]{10}{*}{0.712} & $\begin{array}{l}\text { Pharmaceuti } \\
\text { cal } \\
\text { manufacturi } \\
\text { ng }\end{array}$ & $\begin{array}{l}\text { Pharmaceutical } \\
\text { manufacturing }\end{array}$ & 0.100 & 0.071 \\
\hline & & & \multirow{3}{*}{$\begin{array}{l}\text { Equipment } \\
\text { manufacturi } \\
\text { ng }\end{array}$} & Metal products industry & 0.101 & 0.072 \\
\hline & & & & $\begin{array}{l}\text { General and special } \\
\text { equipment manufacturing }\end{array}$ & 0.098 & 0.070 \\
\hline & & & & $\begin{array}{l}\text { Transportation, electrical } \\
\text { and electronic equipment } \\
\text { manufacturing }\end{array}$ & 0.099 & 0.071 \\
\hline & & & \multirow[t]{6}{*}{$\begin{array}{l}\text { Modern } \\
\text { service } \\
\text { industry }\end{array}$} & $\begin{array}{l}\text { Transportation, } \\
\text { warehousing and postal } \\
\text { services }\end{array}$ & 0.100 & 0.071 \\
\hline & & & & $\begin{array}{l}\text { Information transmission, } \\
\text { software and information } \\
\text { technology services }\end{array}$ & 0.101 & 0.072 \\
\hline & & & & Financial industry & 0.099 & 0.070 \\
\hline & & & & $\begin{array}{l}\text { Leasing and business } \\
\text { services }\end{array}$ & 0.100 & 0.071 \\
\hline & & & & $\begin{array}{l}\text { Education, culture, sports } \\
\text { and entertainment }\end{array}$ & 0.102 & 0.073 \\
\hline & & & & Health and social work & 0.101 & 0.072 \\
\hline
\end{tabular}

Table 2 Weights of Shandong New and Old Kinetic Energy Conversion Monthly Monitoring Index System 
Then, according to the synthetic index method, the monthly index of Shandong new and old kinetic energy conversion under the index system is calculated separately. Figure 1 shows the time series of the new and old kinetic energy conversion monthly index in Shandong.

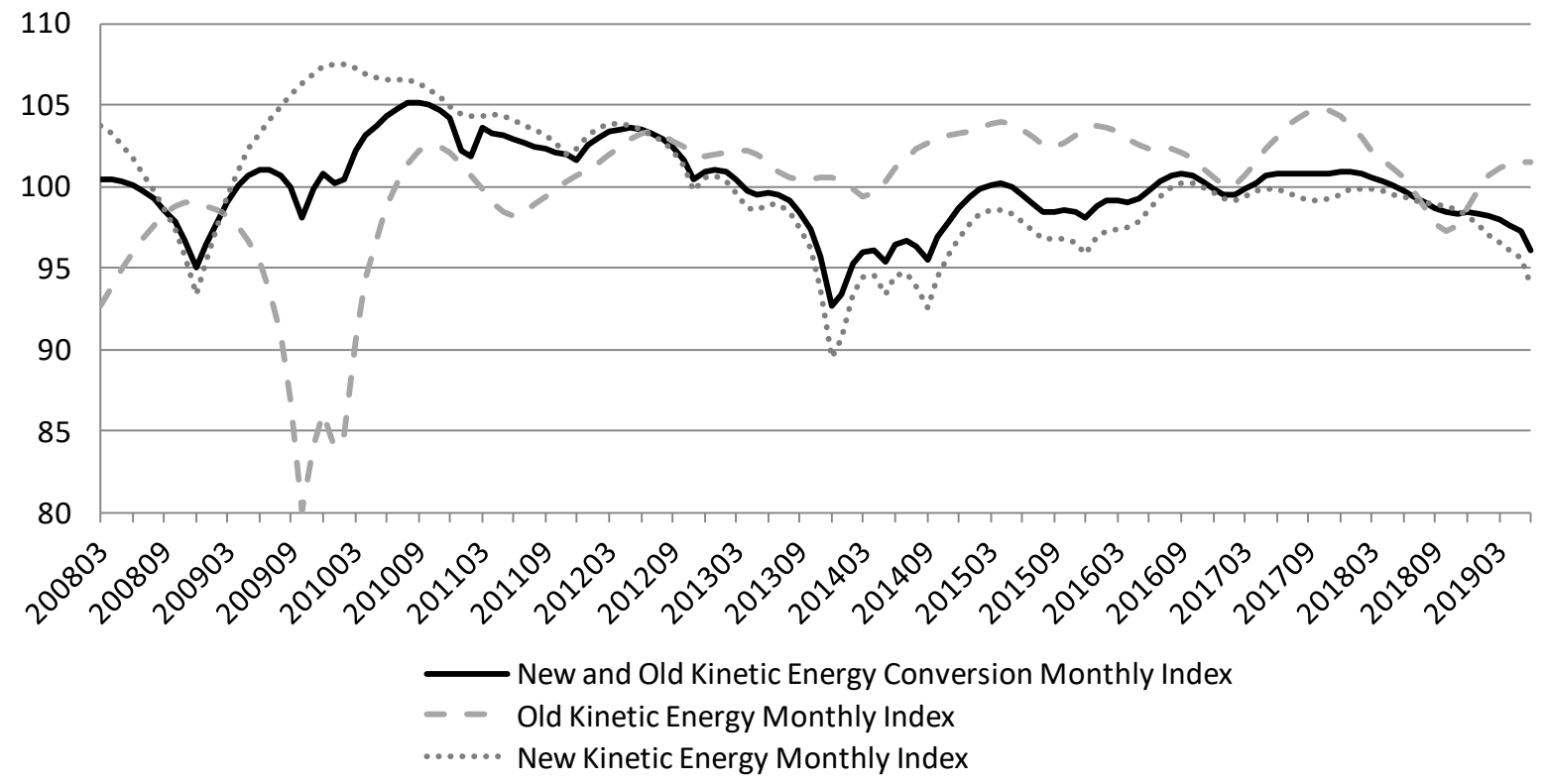

Fig.1. Shandong New and Old Kinetic Energy Conversion Monthly Index

Figure 1 shows that the monthly index of the old and new kinetic energy conversion index system in Shandong showed repeated bifurcation fluctuations from February 2008 to June 2019. Except for the individual months of 2012 and 2017, in most months, the new and old kinetic energy conversion monthly index did not reach 100 . Since 2014, the new and old kinetic energy conversion monthly index has remained at a low level and has not recovered to the previous level. This indicates that the effect of the conversion of old and new kinetic energy in Shandong is still insufficient, and the succession is weak.

From the new kinetic energy monthly index and the old kinetic energy monthly index respectively, before 2013, the new kinetic energy monthly index is higher than the new and old kinetic energy conversion monthly index, while the old kinetic energy monthly index is lower than the old and new kinetic energy conversion monthly index. This shows that during this time, the rapid development of the new kinetic energy industry is the leading force to promote the conversion of new and old kinetic energy in Shandong, while the old kinetic energy industry has hindered the transformation process of new and old kinetic energy in Shandong. After 2013, the old kinetic energy monthly index began to be higher than the new and old kinetic energy conversion monthly index, and in most months it was greater than 100, while the new kinetic energy monthly index performed poorly, lower than the old kinetic energy monthly index. After 2013, the energy efficiency of the old kinetic energy industry in Shandong has been improved or developed relatively slowly, which helps to promote the conversion of new and old kinetic energy in Shandong. However, the lack of development of the new kinetic energy industry has made the transformation of the benign structure of the old and new kinetic energy conversion unsuccessful.

\section{Summary}

This paper builds a new and old kinetic energy conversion monthly monitoring index system based on power demand data, and measures the new and old kinetic energy conversion monthly index of Shandong. Main conclusions are as follows.

Shandong's new and old kinetic energy conversion development momentum is insufficient. Except for the individual months of 2012 and 2017, the old and new kinetic energy conversion indices of the old caliber did not reach 100 in most months. Since 2014, the old and new kinetic energy conversion 
index of the old caliber has remained at a low level, indicating that the effects of the conversion of old and new kinetic energy in Shandong are still insufficient, and the succession is weak.

Shandong's old kinetic energy has achieved remarkable results in eliminating backward production capacity, but the new kinetic energy failed to achieve effective connection conversion. Before 2013, the new kinetic energy monthly index was mostly higher than the old kinetic energy monthly index. The rapid development of the new kinetic energy industry is the leading force to promote the conversion of new and old kinetic energy in Shandong, while the old kinetic energy industry has hindered the conversion process of new and old kinetic energy in Shandong. Since 2013, the old kinetic energy index is mostly higher than the new kinetic energy index, indicating that the old kinetic energy has achieved remarkable results in eliminating backward production capacity, but the lack of development of the new kinetic energy industry has made the conversion of new and old kinetic energy slower.

\section{Acknowledgment}

This article is supported by 2018 Science and Technology Project of State Grid Corporation of China (Research and Application of Quantitative Evolution Model of New Energy Industry Format Development Based on New Consumption Pattern, No. SGHE0000KXJS1800549).

\section{References}

[1] Sun Xiumei, Hou Shiqi. Research on Performance Evaluation of New and Old Kinetic Energy Conversion Based on Analytic Hierarchy-Fuzzy Comprehensive Evaluation Method[J]. Journal of Shandong University of Technology(Social Science Edition), 2019,35(01):9-14.

[2] Zhang Lingling, Xu Liuyi. Measurement and Evaluation of the Transformation of New and Old Kinetic Energy in Wuhan City under Comparative Vision [J]. Three Gorges Forum (Three Gorges Literature • Theoretical Edition), 2019 (05): 90-94+116.

[3] Li Mengxin, Ren Baoping. The framework, current situation and path of economic new kinetic energy cultivation in the western region in the new era [J/OL]. Western Forum: 1-14[2019-10-18]. http: //kns.cnki. Net/kcms/detail/50.1200.C.20190903.1001.004.html.

[4] Liu Qitao, Wang Lei. Research on the measurement of old and new kinetic energy conversion index [J]. China's national conditions, national strength, 2018 (09): 52-54.

[5] Xu Pengjie. Kinetic Energy Conversion, Basic Public Service and Economic Balance Development [J]. Regional Research and Development, 2019, 38 (01): 6-10. 